\title{
Traditional Therapeutic Approach for the Management of Non-Healing, Chronic Diabetic Ulcer - A Case Report
}

\author{
Gomathi Ramaswamy1, Preetheekha Elangovan², Mammallan Arumugam³, Shanmugapriya ponnappan4, \\ Subathra thangamani ${ }^{5}$, Thamodharan Sakthivel ${ }^{6}$, Ujjeevanam Govindan ${ }^{7}$, Vanitha kamatchi ${ }^{8}$
}

\begin{abstract}
${ }^{1}$ Department of Medicine, National Institute of Siddha, Chennai, Tamilnadu, India, ${ }^{2}$ Department of Paediatrics, National Institute of Siddha, Chennai, Tamilnadu, India, ${ }^{3}$ Primary Health Centre, Virudhunagar, Tamilnadu, India, ${ }^{4}$ Department of Toxicology, National Institute of Siddha, Chennai, Tamilnadu, India, ${ }^{5}$ Department of Community Medicine, Sri Sairam Siddha Medical College and Research Centre, Chennai, Tamilnadu, India, 6 Department of Toxicology, Government Siddha Medical College, Chennai, Tamilnadu, India, ${ }^{7}$ Department of Medicine, Government Siddha Medical College, Chennai, Tamilnadu, India, ${ }^{8}$ Department of Medicine, Government Siddha Medical College, Palayamkottai, Tirunelveli, Tamilnadu, India.
\end{abstract}

\section{INTRODUCTION}

Diabetic ulcer is an outcome of the combined effect of diabetes related vascular disease and neuropathy. ${ }^{1}$ People prone to diabetes mellitus across the world were estimated to be 131 million in 2000; it is expected to increase to 366 million by $2030 .{ }^{2}$ According to several studies, about $25-50 \%$ of diabetic patients receive instantaneous amputation at the first visit due to the infection. ${ }^{3}$ Slight injury to glucose laden tissue will cause infection which is progressed by an ulcer and it tends to a state of non-healing which has been shown to precede amputation up to $85 \%$ of cases. ${ }^{4,5}$

Diabetic ulcer management in the contemporary science includes drainage of pus, debridement of dead tissue, local amputation of necrotic digits and antibiotics. ${ }^{6}$ Siddha system of medicine also has 64 unique categories of internal and external medicines including 32 in each. ${ }^{7}$ Both these ends have their own strengths and limitations too. Though treating a non-healing diabetic ulcer is a very big challenge in the current scenario, an integrated approach will give a light on the path of successful management.

\section{PRESENTATION OF CASE}

A 27-year-old male patient approached our clinic, on 28. 03. 2017 presented with complaints of foul smelling, necrotizing, and non-healing oozing ulcer in the ventral aspect of the middle finger of the left hand since 2 months. Patient was apparently healthy about 2 months back, but gradually developed pustules since then which appeared over the ventral aspect of the middle finger of left hand. As the pus collection increased, he went to a physician, where they did an incision to drain the pus. Even after incision, pus collection extended to the whole finger. So, he again visited the same physician where the whole finger was incised for drainage of pus. This later became a non-healing ulcer in spite of medication. There was no history of injury before the onset of ulcer. As the wound showed no signs of improvement, he was referred to a vascular surgeon where he was advised to undergo skin grafting.

He came to Siddha hospital for management because of his unwillingness to do that. He was a newly diagnosed known case of Type - II Diabetes Mellitus and presently on insulin Inj. Human Mixtard (15 - 0 - 15 units). He was not a known case of other systemic diseases.
Corresponding Author: Dr. Gomathi Ramaswamy, Department of Medicine, National Institute of Siddha, Chennai - 47, Tamilnadu, India. E-mail: kgmgomathi@gmail.com

DOI: $10.14260 /$ jemds/2021/483

How to Cite This Article:

Ramaswamy G, Elangovan P, Arumugam $M$, et al. Traditional therapeutic approach for the management of non - healing, chronic diabetic ulcer - a case report. J Evolution Med Dent Sci 2021;10(30): 2358-2361 DOI: 10.14260/jemds/2021/483

Submission 12-05-2021, Peer Review 04-07-2021, Acceptance 11-07-2021, Published 26-07-2021.

Copyright (C) 2021 Gomathi Ramaswamy et al. This is an open access article distributed under Creative Commons Attribution License [Attribution 4.0 International (CC $B Y 4.0)]$ 


\section{CLINICAL DIAGNOSIS}

Examination of ulcer revealed that its location was ventral aspect of the left middle finger, Size $-8 * 21 / 2 \mathrm{~cm}$, Floor sloughed, pallor in which almost $2 \mathrm{~cm}$ of the the skin got necrosed and started forming gangrene, Number - 1, Shape Irregular and ill-defined, Discharge - purulent and foul smelling, Edges - Undetermined edge, Surroundings - Red and oedematous with black discolouration, Touch to bleed Absent, Granulation tissue - Absent. General examination revealed that Appearance - Distressed, Body Built Moderate, Conjunctiva - Normal, Icterus - absent, Lymph Nodes - 1 - 2 axillary lymph nodes were palpable \& Non Tender, Temperature - 98.60 F, Pulse - 70 bpm, B. P - 120 / $70 \mathrm{~mm}$ of Hg, Respiration -17 cycles / min, Height $-169 \mathrm{~cm}$, Weight - $60 \mathrm{~kg}$, BMI - 21 Siddha Envagai Thervu (Examination) revealed that Naa (Tongue examination): Pale, Coated tongue, Niram (Colour of body): Moderate Brown, Mozhi (Speech Examination): Normal, Vizhi (Eye Examination): Normal, Malam (Stool Examination): Pale brown, Soft, Well informed consistency, NeerKuri (Urine Examination): Normal, Straw coloured urine, NeiKuri (Urine Examination with oil immersion): Oil on urine stood like Pearl indicating Kabakuttram, Naadi (Pulse Diagnosis): Kabavaadham.

Systematic examination revealed that cardiovascular system - Audible S1, S2, no added sounds; Central nervous system - Normal mental status, sensory, motor neurological functions were normal; Glasgow Coma scale - Score was 15 with normal level of consciousness, well oriented to time, place and person; Respiratory system - Normal vesicular and bronchial breathing; Abdomen Examination - non-tender, soft. Lab investigations on his first visit revealed that FBS (Fasting Blood Sugar) - 218 mg / dl, PPG (postprandial blood glucose) - $387 \mathrm{mg} / \mathrm{dl}$, HbA1c- $10.5 \%$.

\section{DISCUSSION OF MANAGEMENT}

\begin{tabular}{|c|c|c|c|c|}
\hline \multicolumn{2}{|c|}{ Intervention } & Dose & Adjuvant & \multirow{3}{*}{$\begin{array}{c}\text { Duration } \\
\text { Weekly once } \\
\text { Once (Prior } \\
\text { to start of } \\
\text { Internal } \\
\text { Medicine) }\end{array}$} \\
\hline & Day - 1Chukku oil & $50 \mathrm{ml}$ & Oil bath & \\
\hline & Day - 2 Vellai ennai & $25 \mathrm{ml}$ & $\begin{array}{l}\text { Warm water / } \\
\text { before food / for } \\
\text { purgation }\end{array}$ & \\
\hline $\begin{array}{l}\text { Day 3: Drug } \\
\text { holiday }\end{array}$ & $\begin{array}{c}\text { Day - } 4 \\
\text { Navakiragavellai }\end{array}$ & $65 \mathrm{mg}[\mathrm{bd}]$ & $\begin{array}{c}\text { Palm jiggery / after } \\
\text { food [salt, tamarind } \\
\text { restricted diet] only } \\
\text { milk rice, milk kanji, } \\
\text { palm jaggery water, } \\
\text { pepper water ] }\end{array}$ & 3 days \\
\hline $\begin{array}{l}\text { Day - } 70 \\
\text { mapaal bath }\end{array}$ & Day - 8 Chukku oil & $50 \mathrm{ml}$ & Oil bath & 1 day \\
\hline \multirow[t]{2}{*}{$\begin{array}{l}\text { Day 9: Drug } \\
\text { holiday }\end{array}$} & $\begin{array}{c}\text { Day - } 10 \\
\text { 1.Tab. madhumega } \\
\text { chooranam }\end{array}$ & $2[\mathrm{tds}]$ & $\begin{array}{l}\text { Warm water } \\
\text { (before food) }\end{array}$ & \multirow[t]{2}{*}{$\begin{array}{l}\text { Followed for } \\
3 \text { months }\end{array}$} \\
\hline & 2. Aavarai kudineer & $60 \mathrm{ml}[\mathrm{bd}]$ & Before food & \\
\hline \multicolumn{5}{|c|}{ Table 1. Treatment Plan } \\
\hline
\end{tabular}

- Primarily, the patient was prepared for purgation by following the protocol

- Patient was given oleation with 'ChukkuThailam'.

- The next day purgation medicine 'Vellai ennai was given with warm water for purgation

- $\quad$ Third day, the patient was allowed to take rest

- From day 4, 'Navagraha vellai' and internal medicine were administered twice a day with palm jaggery for 3 consecutive days.

- On Day 7, patient was advised to take Omapaal (Trachyspermum ammi) head bath.

- On day 8, Oleation with Chukku thailam followed by oneday rest.

- In the meantime, patient was allowed to take his regular medication for diabetes.

- Dressing of wound was carried out with Purai ennai which was preceded by Padigara neer wash from 17th day until the complete healing on 42th day.

- Later the patient was advised to follow tablet Madhumega Chooranam and Aavaarai Kudineer for the next 2 months along with daily dressing until the complete

healing.

\begin{tabular}{|c|c|c|c|}
\hline Date & Findings & Intervention & Outcome \\
\hline 28.3.2017 & $\begin{array}{l}\text { Patient visited and diagnosed as } \\
\text { kabavathavirenam [diabetic ulcer] }\end{array}$ & $\begin{array}{l}\text { Allopathic internal and external treatment } \\
\text { given started with oral antibiotics and plus } \\
\text { insulin }\end{array}$ & No improvement in wound and in blood sugar level \\
\hline 29.3.2017 to 31.3.2017 & $\begin{array}{l}\text { Patient was constantly febrile, blood sugar levels } \\
\text { and RFT, LFT, CBC were monitored }\end{array}$ & $\begin{array}{l}\text { Siddha internal and external treatment } \\
\text { were started along with antibiotics and } \\
\text { anti-diabetic drugs continued }\end{array}$ & Pain and pus discharge slightly controlled \\
\hline 31.3.2017 to 4.4 .2017 & $\begin{array}{l}\text { Decision for sterile dressing daily to reduce } \\
\text { wound discharge and for quick healing }\end{array}$ & $\begin{array}{l}\text { Dressing with puraiennai [traditional } \\
\text { Siddha preparation] }\end{array}$ & $\begin{array}{l}\text { Blood sugar level well controlled, no discharge and foul smell } \\
\text { in the wound }\end{array}$ \\
\hline 4.4.2017 to 15.4 .2017 & $\begin{array}{l}\text { Satisfactory wound healing, nails in all fingers } \\
\text { were removed safely }\end{array}$ & $\begin{array}{c}\text { Siddha internal medication and external } \\
\text { dressing }\end{array}$ & Flickering movement present, slightly able to flex the finger \\
\hline 15.4.2017 to 20.4 .2017 & $\begin{array}{l}\text { He came with complaints of giddiness throughout } \\
\text { the day }\end{array}$ & $\begin{array}{l}\text { On 20.4.2017,10.00 } \\
\text { am we gave Siddha medication } \\
\text { elathychooranam } 2 \mathrm{gm} \text { [od] }\end{array}$ & After 15 minutes he relieved from giddiness \\
\hline 21.4.2017, 22.4.2017 & We advised to take blood sugar levels & $\begin{array}{l}\mathrm{F}: 60 \mathrm{mg} / \mathrm{dl} \\
\text { Advice the patient to go to KMC and consult } \\
\text { diabetologist to reduce the dose of insulin }\end{array}$ & $\begin{array}{l}\text { He went to KMC and diabetologist tapered the insulin } 7 \text { units, } \\
\text { now he took } 8 \text { units of insulin [bd] }\end{array}$ \\
\hline 23.4.2017 to 28.4 .2017 & $\begin{array}{l}\text { Wound with healthy granulation tissue filling } \\
\text { from below }\end{array}$ & $\begin{array}{l}\text { Siddha internal medication and external } \\
\text { dressing done }\end{array}$ & $\begin{array}{l}\text { Wound margins and floor healthy, no discharge and pain get } \\
\text { reduced well }\end{array}$ \\
\hline 28.4.2017 to 5.5.2017 & Wound healthy & $\begin{array}{l}\text { Siddha internal and puraiennai dressing } \\
\text { done }\end{array}$ & Good skin growth up to $3 \mathrm{~cm}$ of left middle finger \\
\hline 5.5 .2017 to 10.5 .2017 & $\begin{array}{l}\text { Wound margins and floor were healthy with } \\
\text { healthy granulomatous tissue }\end{array}$ & $\begin{array}{l}\text { Siddha internal and external medication } \\
\text { given }\end{array}$ & $\begin{array}{l}\text { Pain got fully reduced, no pus discharge, new eukaryotic cells } \\
\text { started forming, necrosed tissue got reduced after } 3 \text { months } \\
\text { the patient was received, wound was completely healed, and } \\
\text { there was good healthy skin. He was following siddha } \\
\text { medication for diabetes, till date he is following medication for } \\
\text { diabetes, for every three months F, PP, HbA1C were monitored } \\
\text { Now he is taking only Siddha medication for diabetes, and has } \\
\text { completely stopped allopathic medication. }\end{array}$ \\
\hline
\end{tabular}




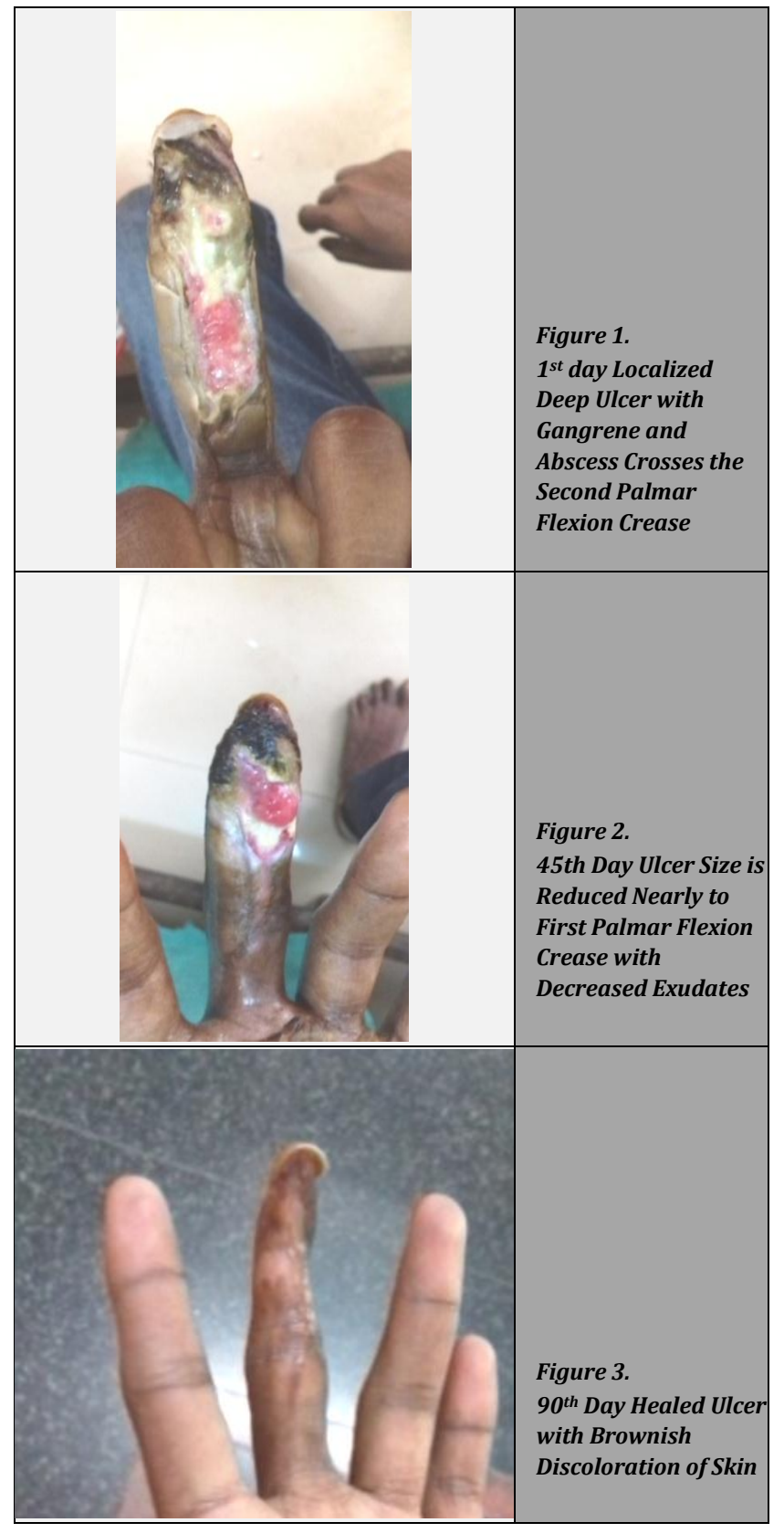

DISCUSSION

Diabetic ulcers are caused by predisposing factors, triggering factors, and aggravating factors. These factors lead to neuropathy and angiopathy finally ischemia, oedema, abnormal immunity and infection. The mechanism of diabetic ulcer is a complicated one. In developing countries, absence of educational training on diabetes and lower financial status contribute to diabetic ulcers, ultimately prompting amputation. The fundamental reasons for neuropathy and angiopathy are hyperglycaemic conditions and other metabolic issues. Thus, keeping up homeostasis of the internal condition and controlling blood glucose are the need of the hour.

By following this protocol, hyperglycaemias were corrected and HbA1c was 7.4 \%, Fasting blood sugar was 102 $\mathrm{mg} / \mathrm{dl}$, postprandial blood sugar was $167 \mathrm{mg}$ / dl which was gradually achieved. Oleation therapy and purgation are preparatory procedures which help in strengthening the spiritual energy and maintenance of uyirthathukkal (vatham, pitham, kabham) in its proportion.

Navagrahavellai is a siddha proprietary medicine for stabbing pain and wounds. By using this medicine and repeated dressing with puraiennai which was preceded with padigaraneer the ulcer had undergone transformation from inflammatory phase to granulation phase within 6 days of siddha medication (28. 3. 2017 - 04. 04. 2017). Scabs began to form on the 6th day. Madhumegachooranam, a avaraikudineer boosts the maintenance of homeostatic condition. So granulation became evident which then gradually grew and covered the wound bed. On follow ups, there was no relapse of ulcer and the finger had maintained the mobility.

According to the literature, deranged pitha humour leads to incidence of Madhumegam. (Diabetes mellitus). In this case affects to Siddha scenario, increased pitha humour affects kabhahumour which in turn vatha humour. Since, the humour derangement changes from pitham to kabavatham, diabetes develops its complication in due course. Ennai Muzhukku (Oleation therapy) was a preparatory procedure which helped in strengthening the spiritual energy and maintenance of Tridosha in its proportion. ${ }^{8}$
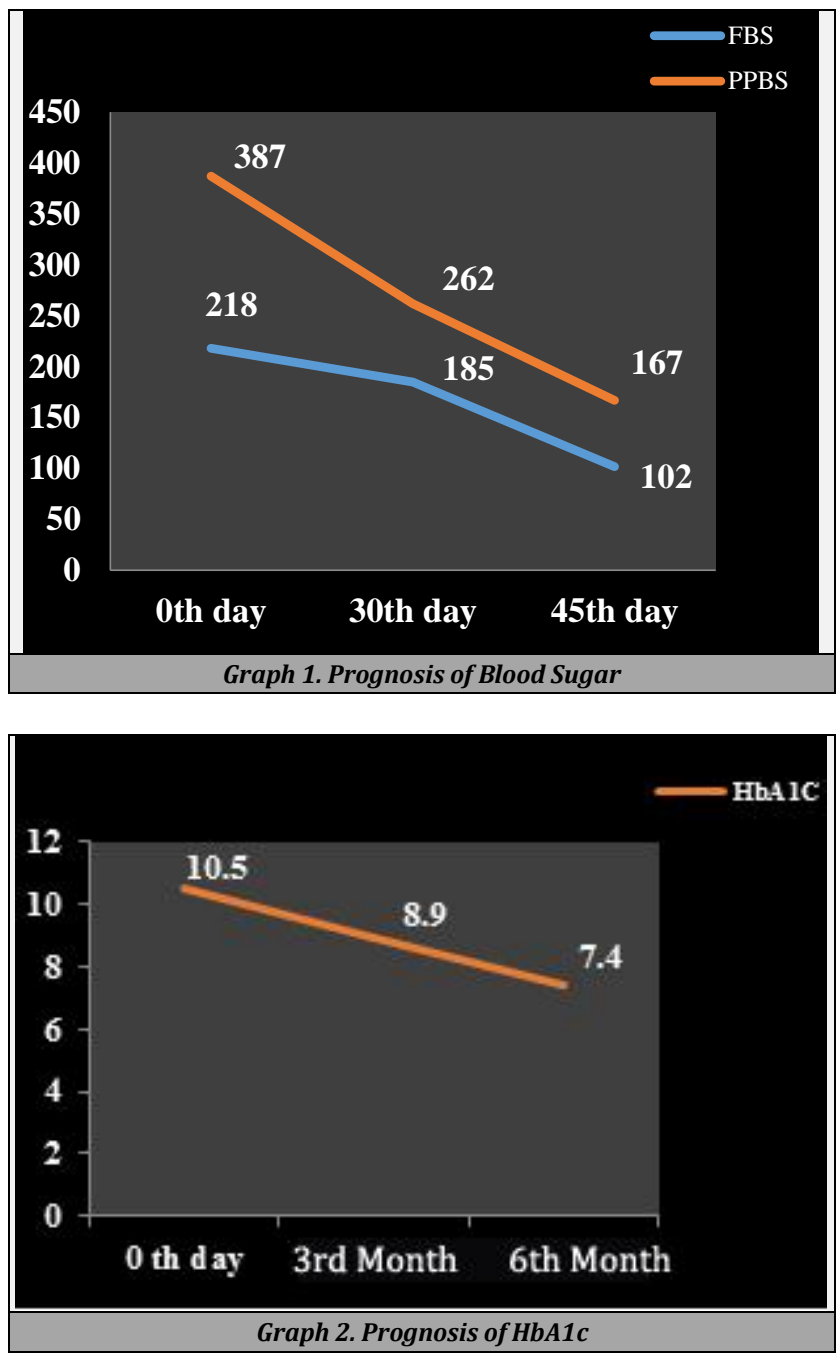

As mentioned in "VaithiyaSaaraSangraham", Purgative medicine was included in the protocol next to oil bath for the purpose of balancing vitiated vatha humour which prevented the spreading nature of wound and enhanced its healing 
reaction. Herbo-mineral drugs have many advantages like more efficacy in minimum dose, quick action, prolonged shelf life and palatability. ${ }^{9}$

Hence, we prefer "NavagrahaVellai" as our primary drug for wound healing. According to the literature, astringent based drug promotes the wound healing property. Our external drug of choice "PuraiEnnai" has many ingredients with astringent and wound healing properties; this plays a vital role in good prognosis. Thus, the combined therapy of both internal and external medicines will help in good prognosis of diabetic ulcer.

\section{CONCLUSIONS}

This current study shows a good prognosis in a chronic nonhealing diabetic ulcer treated with both internal and external integrated medicines. This also creates an interest in treating non-healing ulcers with the other higher order medicines meant for wound healing.

Financial or other competing interests: None.

Disclosure forms provided by the authors are available with the full text of this article at jemds.com.

\section{REFERENCES}

[1] Bhandari M, Rao PN, Gopikrishna BJ, et al. An integrated approach for the management of diabetic foot ulcer: a case report. J Complement Integr Med 2019;16(3):1-6.

[2] Wild S, Roglic G, Green A, et al. Global prevalence of diabetes: estimates for the year 2000 and projections for 2030. Diabetes Care 2004;27(5):1047-53.

[3] Leone S, Pascale R, Vitale M, et al. Epidemiology of diabetic foot. Infez Med 2012;20(Suppl 1):8-13.

[4] Saurabh, Prashanth K, Rakesh RN. Ayurvedic intervention in the management of diabetic foot ulcer-a case report. Int Ayurvedic Med J 2016;4(8):2671-5.

[5] Kumar RC, Fathima SA. Management of diabetic foot ulcer by Nishadi yoga avachoornana-a case study. J Ayurveda Integr Med Sci 2017;2(06):137-41.

[6] Neelambika GB, Balu V, Rego MR, et al. Integrative approach for diabetic foot management-a case report. J Ayurveda Integr Med 2018;9(4):298-301.

[7] Janani L, Christian GJ, Gurumanekandan A, et al. Review on external medicines in siddha system of medicine. International Journal of Research in Pharmaceutical and Nano Sciences 2017;6(1):16-25.

[8] Dhiman A, Janani. A traditional review on oil bath. Int Ayurvedic Med J 2017;5(2):443-6.

[9] Devi BR, Reddy GD, Kumar GVN, et al. Herbomineral formulation's safety and efficacy employed in siddha system of medicine: a review. Int Res J Pharm 2019;10(1):16-24. 